\title{
Evaluation of tropospheric ozone columns derived from assimilated GOME ozone profile observations
}

\author{
A. T. J. de Laat, R. J. van der A, and M. van Weele \\ Royal Netherlands Metrological Institute (KNM), P.O. Box 201, 3730 AE, de Bilt, the Netherlands
}

Received: 27 February 2009 - Published in Atmos. Chem. Phys. Discuss.: 13 May 2009

Revised: 23 September 2009 - Accepted: 13 October 2009 - Published: 28 October 2009

\begin{abstract}
Tropospheric $\mathrm{O}_{3}$ column estimates are produced and evaluated from spaceborne $\mathrm{O}_{3}$ observations by the subtraction of assimilated $\mathrm{O}_{3}$ profile observations from total column observations, the so-called Tropospheric $\mathrm{O}_{3}$ ReAnalysis or TORA method. Here we apply the TORA method to six years (1996-2001) of ERS-2 GOME/TOMS total $\mathrm{O}_{3}$ and ERS-2 GOME $\mathrm{O}_{3}$ profile observations using the TM5 global chemistry-transport model with a linearized $\mathrm{O}_{3}$ photochemistry parameterization scheme.

Free running TM5 simulations show good agreement with $\mathrm{O}_{3}$ sonde observations in the upper-tropospheric and lower stratospheric region (UTLS), both for short day-to-day variability as well as for monthly means. The assimilation of GOME $\mathrm{O}_{3}$ profile observations counteracts the mid-latitude stratospheric $\mathrm{O}_{3}$ drift caused by the overstrong stratospheric meridional circulation in TM5. Assimilation of GOME $\mathrm{O}_{3}$ profile observations also improves the bias and correlations in the tropical UTLS region but slightly degrades the modelto-sonde correlations and bias of extra-tropical UTLS. We suggest that this degradation is related to the large ground pixel size of the GOME $\mathrm{O}_{3}$ measurements $(960 \times 100 \mathrm{~km})$ in combination with retrieval and calibration errors. The added value of the assimilation of GOME $\mathrm{O}_{3}$ profiles compared to stand-alone model simulations lays in the long term variations of stratospheric $\mathrm{O}_{3}$, not in short term synoptic variations.
\end{abstract}

The evaluation of daily and monthly tropospheric $\mathrm{O}_{3}$ columns obtained from total column observations and using

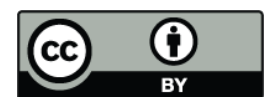

Correspondence to: A. T. J. de Laat (laatdej@knmi.nl) the TORA methodology shows that the use of GOME UVVIS nadir $\mathrm{O}_{3}$ profiles in combination with the spatial resolution of the model does not result in satisfactory residual tropospheric ozone columns.

\section{Introduction}

Global monitoring of tropospheric ozone $\left(\mathrm{O}_{3}\right)$ is a challenge because tropospheric $\mathrm{O}_{3}$ shows large spatio-temporal variability and the number and representativity of observational sites is limited for a complete assessment of long-term global tropospheric $\mathrm{O}_{3}$ trends and tropospheric $\mathrm{O}_{3}$ distribution changes (IPCC, 2007). Satellite observations can potentially contribute in addressing some of the above-mentioned issues, especially the requirement for a global observational network.

Observations of tropospheric $\mathrm{O}_{3}$ from satellites have been reported within the tropics and subtropics - defined as the region from $30^{\circ} \mathrm{S}$ to $30^{\circ} \mathrm{N}$ - for indirect or residual methods. Indirect methods estimate the stratospheric $\mathrm{O}_{3}$ column which is then subtracted from the total $\mathrm{O}_{3}$ column. Their success is to a large extent related to the relatively small tropical stratospheric $\mathrm{O}_{3}$ variability in comparison to tropospheric $\mathrm{O}_{3}$ variability (NRC, 2008). Some success has also been reported for direct observations of tropospheric $\mathrm{O}_{3}$ from UV-VIS nadir $\mathrm{O}_{3}$ profile observations, despite their limited vertical resolution (Liu et al. 2006). However, outside of the tropics the large and rapid tropospheric $\mathrm{O}_{3}$ variability complicates determining tropospheric $\mathrm{O}_{3}$ as it requires individual observations to be of sufficient accuracy (de Laat et al., 2005). In addition, separating between troposphere and

Published by Copernicus Publications on behalf of the European Geosciences Union. 
stratosphere depends on determining the exact location of the tropopause, which is complicated for UV-VIS nadir $\mathrm{O}_{3}$ profile observations because of their limited vertical resolution. As a result, deriving a reliable TTOC from direct $\mathrm{O}_{3}$ profile observations lies at the edge of the satellite observing capability.

Nevertheless, the availability of ozone profile measurements from UV-VIS instruments like GOME (Global Ozone Monitoring Experiment), OMI (Ozone Monitoring Instrument) and GOME-2 and the prospect of continuation of such observations for at least another decade provide a strong incentive to further explore the possibility of using UV-VIS ozone profiles for determining tropospheric $\mathrm{O}_{3}$ columns.

In this paper we introduce a new indirect method for estimating tropospheric $\mathrm{O}_{3}$ columns by assimilation of UVVIS nadir $\mathrm{O}_{3}$ profile measurements and subtracting the resulting stratospheric column from UV-VIS total column $\mathrm{O}_{3}$ observations. The rationale behind this method is that upper tropospheric and lower stratospheric (UTLS) $\mathrm{O}_{3}$ variability and thus the separation between stratosphere and troposphere is dominated by dynamical processes. Photochemical processes are more important in the lower troposphere and in the stratosphere above 25-30 km (Brasseur, 1999). UTLS O 3 variability can be well simulated using a linearized stratospheric $\mathrm{O}_{3}$ chemistry scheme (de Laat et al., 2007). Assimilation of satellite observations of the smooth vertical $\mathrm{O}_{3}$ profiles in a chemistry-transport model will provide an optimal estimate of the stratospheric $\mathrm{O}_{3}$ column, combining small scale dynamical $\mathrm{O}_{3}$ information from the model with the broad scale $\mathrm{O}_{3}$ vertical distribution from the satellite observations. Subtracting the assimilated stratospheric $\mathrm{O}_{3}$ column from a total $\mathrm{O}_{3}$ column observation should then deliver a residual product that is the best estimate for the TTOC. We refer to this method as the Tropospheric $\mathrm{O}_{3} \mathrm{Re}$-Analysis or TORA method. This method can be applied globally and possible gaps in the observational system are filled by the assimilated ozone distribution as determined by the linearized $\mathrm{O}_{3}$ chemistry in the transport model using dynamical information from the weather analyses that forces the model. In this paper, we explore the extent to which satisfactory results can be obtained by applying the TORA method to GOME $\mathrm{O}_{3}$ profiles for the period 1996-2001.

Some success in observing tropospheric $\mathrm{O}_{3}$ outside of the tropics has been reported for other indirect methods, like subtracting the stratospheric $\mathrm{O}_{3}$ column based on $\mathrm{O}_{3}$ profiles from Microwave Limb Sounder (MLS) from OMI total $\mathrm{O}_{3}$ column observations OMI (Schoeberl et al., 2007). MLS observations have a relatively high vertical resolution but do not provide daily global coverage. Therefore, trajectory calculations are used to simulate the advection of MLS observed stratospheric ozone and to reconstruct the daily global vertical distribution of stratospheric $\mathrm{O}_{3}$. Results suggest that this method works quite well and can deliver realistic tropical and mid-latitude tropospheric $\mathrm{O}_{3}$ variations for relatively short time periods (5 days), also at mid-latitudes. The TORA method differs from the approach by Schoeberl et al. (2007) in that meteorological data - which contains information about the dynamics of the UTLS regions - is implicitly used.

Stajner et al. (2008) even go a step further by not only assimilating MLS $\mathrm{O}_{3}$ profiles and OMI total $\mathrm{O}_{3}$ columns in a chemistry-transport model, but also prescribing daily tropospheric $\mathrm{O}_{3}$ production, loss and deposition rates derived from a full tropospheric chemistry-transport model simulation and subsequently investigating modelled tropospheric $\mathrm{O}_{3}$ columns. However, in such an approach it is unclear how much information comes from the observations and how much from the model chemistry, and their results suggest that even without assimilation modelled tropospheric $\mathrm{O}_{3}$ already compares well with independent observations. The TORA method avoids such confusion.

This paper is organized as follows: Sect. 2 briefly describes the setup of the TM5 model and $\mathrm{O}_{3}$ profile assimilation, Sect. 3 describes the observational datasets used in this study, Sect. 4 shows and evaluates the free running and assimilation model results for the UTLS region as well as the for the modelled TTOC's. Finally the calculated TORA residual product is evaluated. Section 5 contains a discussion of the main results, some preliminary conclusions on the TORA methodology as well as recommendations for future work.

\section{$2 \mathrm{TM}_{5} \mathrm{O}_{3}$ profile assimilation}

The TM5 model has been developed at the Institute of Marine and Atmospheric research Utrecht (IMAU) in cooperation with the Royal Netherlands Meteorological Institute (KNMI) and the Dutch Centre for Mathematics and Computer Science (CWI). The TM5 model has been used to study stratospheric chemistry and transport (Bregman et al., 2003; van den Broek et al., 2003, 2004). A detailed description of the TM5 model is given in Krol et al. (2005). The TM5 version used here is the same as in de Laat et al. (2007), using meteorological reanalysis data from the European Centre for Medium-Range Weather Forecasts (ECMWF).

Segers et al. (2005) described the assimilation of GOME nadir $\mathrm{O}_{3}$ profile observations using the TM3 model (TM3 is the predecessor of the TM5 model) in single tracer mode with the linearized $\mathrm{O}_{3}$ chemistry scheme from Cariolle and Deque (1986), hereafter referred to as the "CARIOLLE chemistry". We use updated parameter values from Cariolle and Teyssèdre (2007), but without the use of a cold tracer to represent heterogeneous $\mathrm{O}_{3}$ loss. It is anticipated that GOME $\mathrm{O}_{3}$ profile observations for Antarctic ozone hole conditions are not sufficiently accurate (Meijer et al., 2006). The main focus of this paper is therefore to test the TORA methodology on a day-to-day basis for tropical and mid-latitudes.

The assimilation procedure in Segers et al. (2005) is based on a Kalman filter, and is an extension of the total $\mathrm{O}_{3}$ column assimilation methodology presented by Eskes et al. (2003). 
For this paper the Segers et al. (2005) methodology was adopted and adjusted for use in TM5. The CARIOLLE chemistry has already been used for stand alone TM5 simulations (de Laat et al., 2007). We use the same 44 hybrid-sigma layers between the surface and $0.1 \mathrm{hPa}$, and a horizontal resolution of $3^{\circ} \times 2^{\circ}$ (lon-lat) as in Segers et al. (2005). The 44 layers are a subset of the ECMWF operational 60-layer configuration available for the period 1996-2001. The choice of the 44 layers is related to the focus of the assimilation of producing accurate stratospheric $\mathrm{O}_{3}$ fields and resolving $\mathrm{O}_{3}$ variability in the UTLS region, and includes all ECMWF layers between 10 and $20 \mathrm{~km}$ altitude.

Tropospheric chemistry is not included in the CARIOLLE chemistry. Instead, tropospheric $\mathrm{O}_{3}$ is relaxed towards an $\mathrm{O}_{3}$ climatology (Fortuin and Kelder, 1998) between the surface and $500 \mathrm{hPa}$ altitude with a relaxation time of 14 days. Tests with other tropospheric altitude ranges where the relaxation to the climatology is applied showed little sensitivity to the altitude range definition, as long as lower tropospheric $\mathrm{O}_{3}$ was sufficiently constrained. Note that the TORA methodology only needs the stratospheric $\mathrm{O}_{3}$ distribution from the assimilation results and that the quality of modelled tropospheric $\mathrm{O}_{3}$ is not relevant.

\section{Observations}

\subsection{GOME $\mathrm{O}_{3}$ profile observations}

The GOME $\mathrm{O}_{3}$ profile observations are retrieved using an updated version of the $\mathrm{O}_{3}$ ProfilE Retrieval Algorithm (OPERA). A full description of the algorithm can be found in the Algorithm Theoretical Basis Document (van Oss, 2004) produced for the ESA funded project CHEOPS-GOME (Climatology of Height-resolved Earth-Ozone and Profile Systems for GOME). A detailed validation of GOME OPERA $\mathrm{O}_{3}$ profiles can be found in deClercq (2007). The OPERA version used in this paper is the version R2 as described in deClercq (2007). A detailed description of recent improvements in the OPERA retrieval algorithm is reported in Mijling et al. (submitted; 2009).

The analysis of the information content of the GOME OPERA $\mathrm{O}_{3}$ profiles (deClercq, 2007) reveals that the amount of information - vertical resolution and sensitivity - has decreased over this period due to instrument degradation. Three periods can be discriminated: 19961998, when information content is at its maximum, 1999 mid-2001, when tropospheric information content degrades progressively and after mid 2001, when stratospheric information content also starts to degrade and when tropospheric information - in particular in the tropics and subtropics - vanishes. Therefore, this paper focuses on the six year period 1996-2001.

Comparison with independent ground-based microwave and $\mathrm{O}_{3}$ sonde profile measurements shows that in the bulk of stratosphere up to $45 \mathrm{~km}$ altitude there is - on average - a good agreement of $10 \%$ and better between the satellite and microwave or sonde measurements until the end of 2001 (deClercq, 2007). In the troposphere the agreement is reasonable outside of the tropics and subtropics with biases of up to $25 \%$, yet worse within the tropics and subtropics. After 1998 effects of the instrument degradation as described above further degrade the comparison in the tropics and subtropics.

Quality checks were applied to the $\mathrm{O}_{3}$ profiles in order to ensure the selection of accurate $\mathrm{O}_{3}$ profile observations. Profiles are checked on standard OPERA quality flags for convergence of the retrieval and out of bounds values (including negatives). Non-convergence may for example occur over snow and icy surfaces (Mijling et al., submitted, 2009).

\subsection{Total $\mathrm{O}_{3}$ column observations}

The main goal of the TORA methodology presented in this paper is to produce a best estimate of the stratospheric $\mathrm{O}_{3}$ column and subtract this column from a total column observation. This yields tropospheric $\mathrm{O}_{3}$ residuals (or TTOC's). We use GOME total $\mathrm{O}_{3}$ column datasets based on two different retrieval algorithms: DLR GDP v4.1 (van Roozendael et al., 2006; Balis et al., 2007) and TOGOMI v1.2 (Valks et al., 2004) as well as TOMS v8 total $\mathrm{O}_{3}$ column observations (Bhartia, 2004). These total $\mathrm{O}_{3}$ column measurements have a pixel size of about $320 \times 40 \mathrm{~km}$, which is significantly smaller than the footprint of the GOME $\mathrm{O}_{3}$ profile observations $(960 \times 100 \mathrm{~km})$. Another advantage of the TORA methodology over direct TTOC estimates from $\mathrm{O}_{3}$ profile observations is the use of the better spatial resolution of the total $\mathrm{O}_{3}$ column observations. The assimilation ensures that for every total $\mathrm{O}_{3}$ column observation a value for the stratospheric $\mathrm{O}_{3}$ column can be derived even in case no co-located $\mathrm{O}_{3}$ profile observation is available.

\section{3 $\mathrm{O}_{3}$ sonde observations}

For evaluation of the model simulations with and without assimilation the model profiles are compared with $\mathrm{O}_{3}$ sonde observations. These observations are taken from the World Ozone and Ultraviolet radiation Data Center (WOUDC) database (http://www.woudc.org/) wherever sonde observations were available for the period 19962001. A comparison was made for all available sonde data. Figure 1 shows the geographical locations of the stations summarized in Table SO in the supplementary information: http://www.atmos-chem-phys.net/9/8105/2009/ acp-9-8105-2009-supplement.pdf.

\subsection{ECMWF tropopause heights}

In order to separate between the stratosphere and troposphere for estimating the stratospheric $\mathrm{O}_{3}$ column the tropopause height must be known. Although various tropopause definitions exists, the most commonly used definitions are $2 \mathrm{~K} / \mathrm{km}$ 


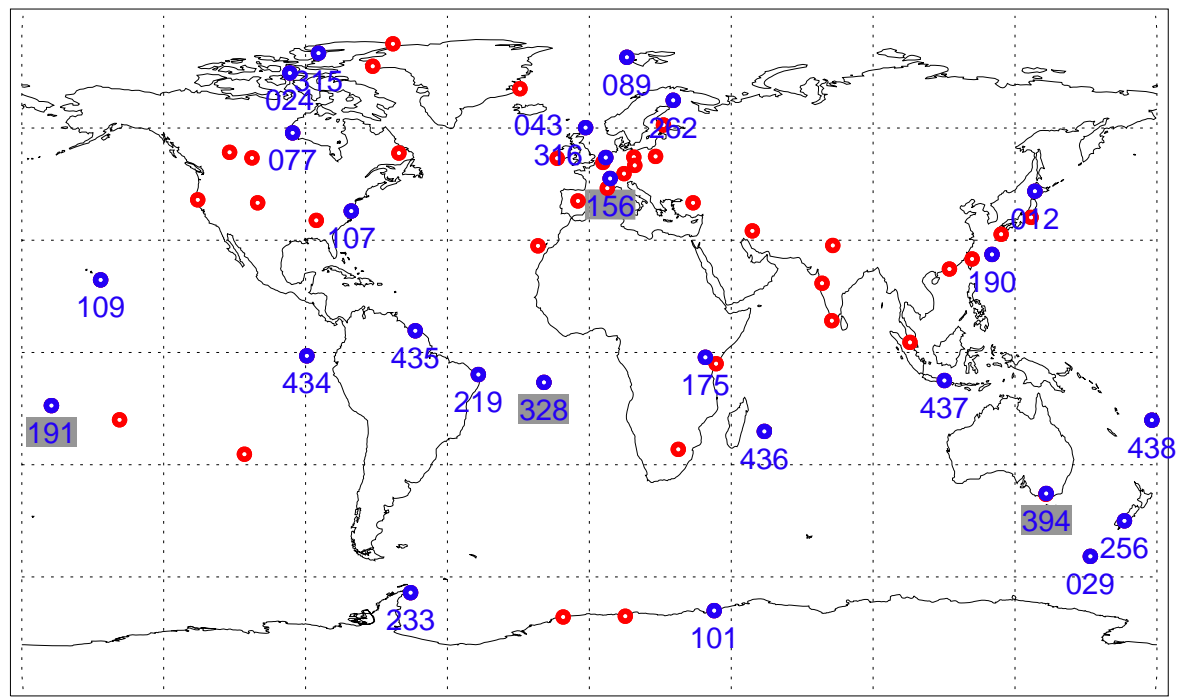

Fig. 1. Locations of WOUDC stations used in this paper. The stations used and discussed in the paper are indicated in blue, including the WOUDC station identifier (see also Table S0: http://www.atmos-chem-phys.net/9/8105/2009/acp-9-8105-2009-supplement.pdf). Additional sondes that have been compared but not discussed in the paper are in red, the results of their comparison can be found in the supplementary information: http://www.atmos-chem-phys.net/9/8105/2009/acp-9-8105-2009-supplement.pdf.

lapse rate within the tropics and subtropics and the use of the Potential Vorticity (PV) unit outside of the tropics and subtropics (here we use the $\mathrm{PV}=3$ contour). ECMWF temperature and ERA40 PV data were used to calculate daily tropopause heights on a $3^{\circ} \times 2^{\circ}$ resolution. Poleward of $40^{\circ}$ the PV definition was used, equatorward of $20^{\circ}$ the temperature-lapse rate definition was used, while between $20^{\circ}$ and $40^{\circ}$ latitudes both definitions were linearly combined to ensure a smooth transition between both definitions. The minimum tropopause height allowed was $5 \mathrm{~km}$ to account for potential lower tropospheric temperature inversions.

\section{Results}

The TORA methodology aims at providing the best estimate for the stratospheric $\mathrm{O}_{3}$ column and subtracting this column from total $\mathrm{O}_{3}$ column observations that will yield - in an ideal case - the total tropospheric $\mathrm{O}_{3}$ column (TTOC) as a residual. First of all, a baseline needs to be defined: how well does a free TM5 run - i.e. without assimilation - compare with sonde observations? Results for UTLS $\mathrm{O}_{3}$ are discussed in Sect. 4.1.1 and for the TTOC in 4.1.2. The next step is to compare the TM5 simulation with assimilation of the GOME $\mathrm{O}_{3}$ profiles with the same set of sonde observations and establish how the comparisons change (Sects. 4.2.1 and 4.2.2, respectively). In addition, the effect of the $\mathrm{O}_{3}$ profile assimilation on the full 6-year modelled UTLS $\mathrm{O}_{3}$ is investigated (Sect. 4.3). After that, the TORA methodology is applied to produce tropospheric $\mathrm{O}_{3}$ residuals and these are again evaluated with the available sonde observations
(Sect. 4.4). Statistics of the one-on-one comparisons are presented, as well as annual mean differences in UTLS $\mathrm{O}_{3}$ for the model simulation with and without assimilation. Finally, we analyse the annual mean spatial distribution of the TORA residuals for the year 2000 .

\subsection{Evaluation of TM5 UTLS $\mathrm{O}_{3}$ with sonde observations}

The CARIOLLE scheme is particularly suited for the simulation of lower and middle stratospheric $\mathrm{O}_{3}$ (up to $25-30 \mathrm{~km}$ altitude) because of the dominance of dynamics over chemistry in this region (Cariolle and Deque, 1986; Cariolle and Teyssèdre, 2007; Geer et al., 2007). This is also the case for the upper troposphere outside of the tropics. In de Laat et al. (2007) we showed in a comparison of GOME $\mathrm{O}_{3}$ profiles with $\mathrm{O}_{3}$ sonde profiles from Payerne, Switzerland, that $\mathrm{O}_{3}$ concentrations at $15 \mathrm{~km}$ altitude agreed very well on both short synoptic and long seasonal time scales, despite the large ground pixel size $(960 \times 100 \mathrm{~km})$ of the GOME $\mathrm{O}_{3}$ profile. Furthermore, a key issue of the TORA methodology - or any tropospheric $\mathrm{O}_{3}$ residual method for that matter - is the separation of the stratosphere from the troposphere and thus a realistic representation of the tropopause. We therefore chose to compare modelled $\mathrm{O}_{3}$ for the layer between 250 and $50 \mathrm{hPa}$ (approximately the $10-20 \mathrm{~km}$ altitude range; hereafter referred to as UTLS column) with sonde observations.

A subset of four $\mathrm{O}_{3}$ sonde locations representative for different tropospheric and stratospheric circumstances is used to illustrate the comparisons between model results and sonde observations. Figure 2 shows the comparison between 
Table 1. TM5 evaluation of UTLS partial $\mathrm{O}_{3}$ columns $(250-50 \mathrm{hPa})$ for a subset of available WOUDC sonde observations. Locations are ordered according to their latitude. The statistics shown here are the standard Pearsons correlation coefficient $(R)$ for the six year period 1996-2001, the correlation for monthly means $(R m)$, the correlation for the 6-year climatological monthly means $(R c l)$, the average bias $(\Delta$; sonde-model) and the root-mean-square differences $(\sigma)$. Biases and differences are in Dobson Units (DU; $2.69 \times 10^{18} \mathrm{molecules}^{2}$ ). Bold italic numbers indicate the better statistical values for the comparison of sonde measurements and model results with assimilation compared to those without assimilation. "Better" refers to larger correlations, smaller biases and smaller rms differences. Stations shown in Fig. 2 are indicated in grey. Statistics for all available sonde stations can be found in supplementary Table S1.: http://www.atmos-chem-phys.net/9/ 8105/2009/acp-9-8105-2009-supplement.pdf.

\begin{tabular}{|c|c|c|c|c|c|c|c|c|c|c|c|}
\hline \multirow[b]{2}{*}{ Station } & \multirow[b]{2}{*}{ lat } & \multicolumn{5}{|c|}{ UTLS (250-50 hPa) assimilated GOME } & \multicolumn{5}{|c|}{ UTLS (250-50 hPa) no assimilation } \\
\hline & & $R$ & $R m$ & Rcl & $\Delta$ & $\sigma$ & $R$ & $R m$ & Rcl & $\Delta$ & $\sigma$ \\
\hline $\operatorname{stn} 315$ & 80.0 & 0.60 & 0.74 & 0.92 & 25.4 & 32.7 & 0.63 & 0.77 & 0.92 & 18.2 & \\
\hline stn089 & 78.9 & 0.56 & 0.73 & 0.96 & 9.6 & 32.1 & 0.57 & 0.75 & 0.94 & 3.2 & 32.3 \\
\hline stn024 & 74.7 & 0.76 & 0.85 & 0.95 & 20.0 & 27.9 & 0.78 & 0.84 & 0.95 & 12.9 & 26.6 \\
\hline $\operatorname{stn} 262$ & 67.4 & 0.72 & 0.82 & 0.97 & 1.6 & 25.1 & 0.76 & 0.85 & 0.97 & -2.0 & 23.5 \\
\hline stn043 & 60.1 & 0.79 & 0.89 & 0.98 & 6.5 & 23.8 & 0.85 & 0.93 & 0.99 & 3.1 & 20.8 \\
\hline stn077 & 58.7 & 0.82 & 0.89 & 0.98 & 17.8 & 26.5 & 0.84 & 0.91 & 0.98 & 9.6 & 24.6 \\
\hline $\operatorname{stn} 316$ & 52.1 & 0.73 & 0.85 & 0.97 & -1.3 & 23.1 & 0.80 & 0.89 & 0.98 & -6.2 & 20.3 \\
\hline stn156 & 46.5 & 0.76 & 0.88 & 0.98 & 1.4 & 19.2 & 0.84 & 0.93 & 0.99 & -4.0 & 15.9 \\
\hline $\operatorname{stn} 012$ & 43.1 & 0.88 & 0.95 & 1.00 & -0.9 & 20.2 & 0.92 & 0.96 & 0.99 & -10.3 & 16.6 \\
\hline stn107 & 37.8 & 0.72 & 0.81 & 0.97 & 5.8 & 20.8 & 0.74 & 0.82 & 0.98 & 0.8 & 20.0 \\
\hline $\operatorname{stn} 190$ & 26.2 & 0.45 & 0.48 & 0.60 & -11.7 & 7.7 & 0.47 & 0.54 & 0.69 & -14.2 & 8.1 \\
\hline stn109 & 19.4 & 0.68 & 0.79 & 0.88 & -1.9 & 6.8 & 0.66 & 0.75 & 0.87 & -3.8 & 7.2 \\
\hline $\operatorname{stn} 435$ & 5.8 & 0.43 & 0.58 & 0.80 & 2.3 & 5.3 & 0.34 & 0.55 & 0.78 & 1.0 & 6.1 \\
\hline $\operatorname{stn} 434$ & -0.9 & 0.33 & 0.43 & 0.69 & -4.0 & 5.3 & 0.32 & 0.42 & 0.67 & -4.5 & 5.5 \\
\hline stn175 & -1.3 & 0.46 & 0.62 & 0.85 & 0.2 & 4.9 & 0.45 & 0.61 & 0.84 & -0.9 & 5.1 \\
\hline $\operatorname{stn} 219$ & -5.9 & 0.37 & 0.53 & 0.87 & -3.1 & 5.3 & 0.29 & 0.49 & 0.82 & -4.1 & 5.8 \\
\hline $\operatorname{stn} 328$ & -8.0 & 0.49 & 0.68 & 0.83 & -0.6 & 5.1 & 0.44 & 0.64 & 0.77 & -1.6 & 5.5 \\
\hline $\operatorname{stn} 191$ & -14.2 & 0.71 & 0.81 & 0.91 & -4.3 & 3.9 & 0.70 & 0.81 & 0.92 & -5.0 & 4.2 \\
\hline $\operatorname{stn} 438$ & -18.1 & 0.57 & 0.67 & 0.93 & -4.7 & 8.7 & 0.62 & 0.70 & 0.95 & -6.3 & 8.5 \\
\hline $\operatorname{stn} 436$ & -21.1 & 0.65 & 0.73 & 0.77 & -1.5 & 5.9 & 0.63 & 0.66 & 0.68 & -3.2 & 7.0 \\
\hline $\operatorname{stn} 394$ & -37.7 & 0.81 & 0.91 & 0.96 & -1.5 & 15.5 & 0.82 & 0.92 & 0.97 & -9.2 & 15.1 \\
\hline $\operatorname{stn} 256$ & -45.0 & 0.83 & 0.94 & 0.97 & 0.5 & 15.8 & 0.88 & 0.96 & 0.98 & -6.4 & 13.3 \\
\hline stn029 & -54.5 & 0.71 & 0.80 & 0.95 & 1.0 & 20.5 & 0.79 & 0.84 & 0.97 & -5.8 & 18.1 \\
\hline $\operatorname{stn} 233$ & -64.2 & 0.48 & 0.39 & 0.59 & -10.3 & 29.1 & 0.55 & 0.49 & 0.56 & -14.4 & 27.7 \\
\hline $\operatorname{stn} 101$ & -69.0 & 0.53 & 0.65 & 0.75 & -8.7 & 35.3 & 0.66 & 0.72 & 0.78 & -12.5 & 32.8 \\
\hline
\end{tabular}

UTLS columns from the TM5 assimilation run and sonde observations for the four location subset: Payerne, Switzerland (stn156; Fig. 2a); Broad Meadows, Australia (stn394; Fig. 2b), Samoa (stn191; Fig.2c) and Ascension Island (stn328; Fig.2d). Payerne and Broad Meadows represent mid-latitude Northern and Southern Hemisphere locations and are characterized by strong seasonal cycles with the largest UTLS columns during local winter, associated with a lower tropopause and thus a larger part of the stratosphere located between 250 and $50 \mathrm{hPa}$. Superimposed on the seasonal cycle are rapid UTLS column variations associated with synoptical scale weather phenomena driven by Rossby wave activity. Figure 2 shows that there is a good agreement between UTLS $\mathrm{O}_{3}$ from the TM5 simulation and sonde observations (see also Table 1). The phases and amplitude of seasonal cycles - as also reflected in the monthly means - and synoptical scale short-term variability are similar. The amplitude of the seasonal cycle and day-to-day synoptic scale variability are larger for Payerne (Fig. 2a) compared to Broad Meadows (Fig. 2b), related to the stronger Northern Hemisphere Rossby wave activity for Payerne. For individual days differences do occur. For example, for Payerne the sonde observations show at the beginning of 1999 larger UTLS $\mathrm{O}_{3}$ compared to the model results. These differences are likely related to model resolution and representativity of the sonde data as well as to the exact timing of UTLS events by for example rapidly travelling frontal zones and the corresponding time differences of the $\mathrm{O}_{3}$ sonde measurements (mainly around local noon) and the time of model output (always at 12:00 UTC).

Figure $2 b$ and $c$ show two tropical locations: Ascention Island for the equatorial Atlantic Ocean and Samoa for the equatorial Pacific Ocean. The seasonal cycles for both 

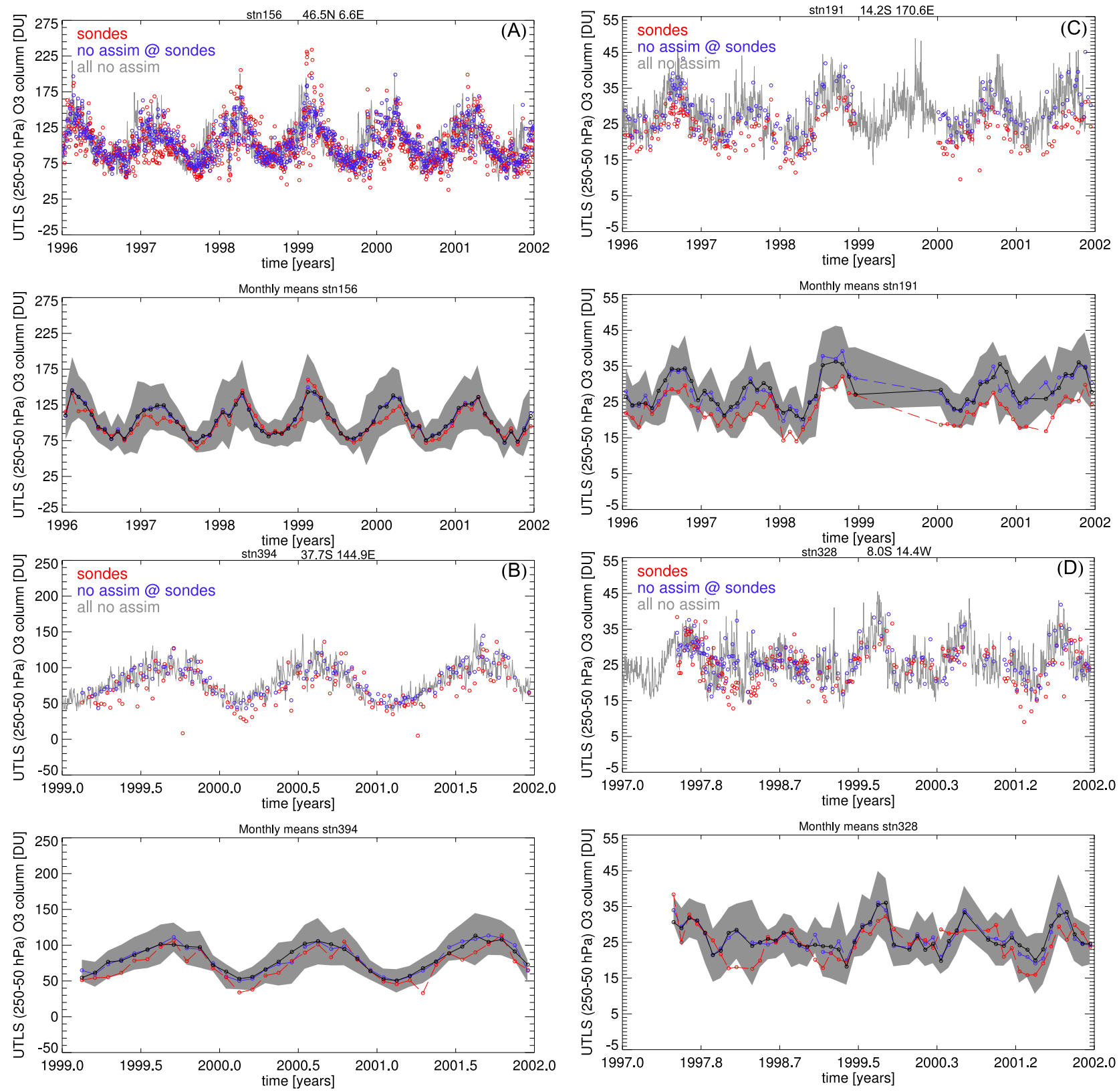

Fig. 2. Comparison of UTLS partial columns - between 250 and $50 \mathrm{hPa}$ altitude - from the TM5 free model run and WOUDC $\mathrm{O}_{3}$ sondes for the period 1996-2001 for four locations: (A) Payerne, Switzerland (stn156); (B) Broad Meadows, Australia (stn394), (C) Samoa (stn191) and (D) Ascension Island (stn328). See Fig. 1 and Table S0 http://www.atmos-chem-phys.net/9/8105/2009/acp-9-8105-2009-supplement.pdf for location details. For each location, the upper panel shows the observed (red) and modelled daily UTLS columns (blue markers: collocated with sondes; grey lines: all modelled columns). The lower panel for each location shows the corresponding monthly means including the variability envelope $(2 \sigma)$ of all modelled daily columns within that particular month (grey shading).

locations are much smaller in amplitude than those at the mid-latitude locations. This is partly related to the smaller seasonal cycle of the tropical tropopause and tropical lower stratospheric $\mathrm{O}_{3}$, and partly due to the higher tropopause in the tropics and subtropics so that a smaller part of the stratosphere is located between 250 and $50 \mathrm{hPa}$. The free-running
TM5 simulation also agrees rather well with tropical observations and captures the synoptic-scale, seasonal and interannual variability in the tropical UTLS. A small positive model bias appears for Samoa (Fig. 2d; 5 DU, see Table 1). This bias is related to the zonal mean tropospheric ozone climatology used in the simulations which because of the zonal 
wave-1 pattern of tropical tropospheric $\mathrm{O}_{3}$ with a minimum over the Pacific leads to an overestimation of the modelled $\mathrm{UTLS} \mathrm{O}_{3}$ for the equatorial Pacific.

Table 1 summarizes the comparison between modelled and sonde observed UTLS variability for a selection of 25 sonde locations over the full range of latitudes. The statistics show that in general at mid-latitudes model results and observations agree well, with correlations varying between 0.55 and 0.92 . The correlations improve considerably for the monthly means, and are even better for the 6-year climatological values, which in many cases are close to 1.0. This suggests that the day-to-day differences caused by synoptical scale variability can be considered random variations, i.e. weather noise which averages out. This variability is large outside of the tropics and subtropics as reflected in the root-mean-square (rms) differences. When looking in detail at the biases, we find that at high northern latitudes $\left(>60^{\circ} \mathrm{N}\right)$ the model slightly underestimates UTLS $\mathrm{O}_{3}$ up to $-5 \%$. For the region between $20^{\circ} \mathrm{N}$ and $60^{\circ} \mathrm{N}$ and $20^{\circ} \mathrm{S}$ and $60^{\circ} \mathrm{S}$ it slightly overestimates UTLS $\mathrm{O}_{3}$ up to $3 \%$. At Southern Hemisphere high latitudes $\left(>60^{\circ} \mathrm{S}\right)$ modelled UTLS $\mathrm{O}_{3}$ is too large up to $10 \%$, caused by the absence of heterogeneous $\mathrm{O}_{3}$ loss in the TM5 model simulation.

In the tropics between $20^{\circ} \mathrm{N}$ and $20^{\circ} \mathrm{S}$, correlations are smaller although also here the correlations improve for monthly and climatological means, while biases and rms differences are small. This different behaviour is caused by the smaller seasonal cycle and the relatively larger influence of tropospheric $\mathrm{O}_{3}$ variability. Spatio-temporal variations in upper tropospheric $\mathrm{O}_{3}$ relate via convection processes to lower tropospheric $\mathrm{O}_{3}$ which is not well reproduced by the TM5 simulations because of the relaxation to the zonal-mean tropospheric climatology and the lack of tropospheric chemistry. Overall, given the use of a linearized $\mathrm{O}_{3}$ chemistry model, the applied model resolution and differences in collocations, the agreement between the free-running TM5 simulation and observed UTLS $\mathrm{O}_{3}$ from sondes is considered rather good.

\subsection{Evaluation of TM5 tropospheric $\mathrm{O}_{3}$ columns with sonde observations}

In the previous section we compared modelled and observed UTLS variability. Since the end goal of this paper is to derive total tropospheric $\mathrm{O}_{3}$ columns (TTOC's), we also briefly investigate the agreement between the free-running TM5 simulation and observed TTOC's as derived from ozone sondes (Table 2). Similar to the UTLS comparison the correlations outside of the tropics and subtropics are larger than within the tropics and subtropics, and correlations improve for monthly and climatological means, although the correlations are slightly worse than for the UTLS columns. The agreement between modelled and observed TTOC variability outside of the tropics and subtropics is closely related to the influence of upper tropospheric $\mathrm{O}_{3}$ and the coupling between upper tropospheric $\mathrm{O}_{3}$ and atmospheric dynamics. The model is well suited to reproduce $\mathrm{O}_{3}$ variations related to such processes. However, the variations are superimposed on a tropospheric $\mathrm{O}_{3}$ climatology which does not result in realistic day-to-day and interannual TTOC variability; hence correlations for TTOC are worse than those for the UTLS. In absolute terms the TTOC bias is smaller, but in relative terms the biases - compared to the mean - are similar for the UTLS column and the TTOC (not shown). The same applies for the rms differences, which are comparable for the UTLS and TTOC relative to the rms variability or mean of the UTLS and TTOC.

\subsection{Evaluation of TM5 assimilation UTLS $\mathrm{O}_{3}$ with sondes}

The next question to address is how the comparison and statistics change when GOME $\mathrm{O}_{3}$ profiles are assimilated in TM5. Table 1 shows that correlations with or without assimilation are comparable for the individual, monthly mean and climatological values. Outside of the tropics and subtropics the correlations are generally worse for the assimilated UTLS columns by a value of up to 0.1 . The differences in correlations are small and the change should be considered insignificant for most cases, but nevertheless this occurs for nearly all sonde locations. On the other hand, within the tropics and subtropics the correlations improve, albeit also slightly. The rms differences follow suite, i.e. the rms differences decrease or increase with decreasing or increasing correlations. The rms values are large for the UTLS columns outside of the tropics and subtropics, reflecting the influence of synoptic scale day-to-day UTLS variability associated with Rossby wave activity, not dissimilar from results in Segers et al. (2005).

Earlier studies have shown that the spatial correlation length of UTLS $\mathrm{O}_{3}$ at mid-latitude locations is about 300$400 \mathrm{~km}$ for the LS and less than $100 \mathrm{~km}$ for the UT (Sparling et al., 2006). These spatial scales are considerably smaller than the size of the GOME pixel $(960 \times 100 \mathrm{~km})$. The question arises whether the $\mathrm{GOME} \mathrm{O}_{3}$ profiles on average contain sufficient and accurate information to improve the already quite good TM5 UTLS $\mathrm{O}_{3}$ profiles from the stand-alone simulation. Furthermore, because of the vertical smoothing of the GOME $\mathrm{O}_{3}$ profile, it becomes very important to know exactly where information of the tropospheric part of the GOME $\mathrm{O}_{3}$ profile originates from (e.g. from climatology in case of obscuring cloudiness). These retrieval uncertainties, together with errors due to measurement biases and uncertainties may degrade the accuracy of the GOME $\mathrm{O}_{3}$ profiles in the UTLS region.

For tropical locations the above mentioned problems may be less of an issue because UTLS variability is smaller, tropospheric $\mathrm{O}_{3}$ variability occurs more on longer temporal time scales compared to mid and high latitudes (de Laat et al., 2005) and the sensitivity of GOME to tropospheric 
Table 2. As Table 1 but for the total tropospheric $\mathrm{O}_{3}$ columns (TTOC's), based on ECMWF tropopause heights. Locations are ordered according to their latitude. The statistics shown here are the standard Pearsons correlation coefficient $(R)$ for the six year period 1996-2001, the correlation for monthly means $(R m)$, the correlation for the 6-year climatological monthly means $(R c l)$, the average bias $(\Delta$; sondemodel) and the root-mean-square differences $(\sigma)$. Biases and differences are in Dobson Units (DU; $2.69 \times 10^{18}$ molecules $\mathrm{cm}^{2}$ ). The bold numbers indicate the better statistical values for the comparison of sonde measurements and model results with assimilation compared to without assimilation. "Better" refers to larger correlations, smaller biases and smaller rms differences. Stations shown in Fig. 2 are indicated in grey. Statistics for all available sonde stations can be found in supplementary table S1: http://www.atmos-chem-phys.net/9/8105/2009/ acp-9-8105-2009-supplement.pdf.

\begin{tabular}{|c|c|c|c|c|c|c|c|c|c|c|c|}
\hline \multirow[b]{2}{*}{ Station } & \multirow[b]{2}{*}{ lat } & \multicolumn{5}{|c|}{ TTOC (surf-tropP) assimilated GOME } & \multicolumn{5}{|c|}{ TTOC (surf-tropP) no assimilation } \\
\hline & & $R$ & $R m$ & Rcl & $\Delta$ & $\sigma$ & $R$ & $R m$ & Rcl & $\Delta$ & $\sigma$ \\
\hline $\operatorname{stn} 315$ & 80.0 & 0.48 & 0.43 & 0.47 & -3.8 & 6.7 & 0.57 & 0.49 & 0.40 & -3.9 & 5.3 \\
\hline stn089 & 78.9 & 0.43 & 0.58 & 0.86 & -4.0 & 7.7 & 0.53 & 0.73 & 0.94 & -4.7 & 6.6 \\
\hline $\operatorname{stn} 024$ & 74.7 & 0.41 & 0.38 & 0.67 & -6.8 & 7.8 & 0.46 & 0.50 & 0.72 & -6.0 & 6.6 \\
\hline $\operatorname{stn} 262$ & 67.4 & 0.48 & 0.67 & 0.69 & -5.7 & 8.0 & 0.74 & 0.81 & 0.90 & -8.1 & 4.8 \\
\hline stn043 & 60.1 & 0.47 & 0.64 & 0.86 & -3.6 & 8.1 & 0.71 & 0.82 & 0.94 & -6.5 & 4.6 \\
\hline stn077 & 58.7 & 0.45 & 0.61 & 0.93 & -3.9 & 8.3 & 0.54 & 0.71 & 0.90 & -5.1 & 6.6 \\
\hline $\operatorname{stn} 316$ & 52.1 & 0.29 & 0.36 & 0.70 & -7.0 & 10.7 & 0.57 & 0.64 & 0.83 & -10.7 & 6.6 \\
\hline $\operatorname{stn} 156$ & 46.5 & 0.51 & 0.79 & 0.86 & -1.5 & 8.2 & 0.65 & 0.83 & 0.90 & -4.2 & 6.1 \\
\hline $\operatorname{stn} 012$ & 43.1 & 0.65 & 0.76 & 0.92 & -7.9 & 7.6 & 0.80 & 0.89 & 0.98 & -7.7 & 5.4 \\
\hline stn107 & 37.8 & 0.67 & 0.83 & 0.93 & -3.3 & 8.0 & 0.74 & 0.87 & 0.95 & -4.1 & 6.4 \\
\hline $\operatorname{stn} 190$ & 26.2 & 0.60 & 0.66 & 0.72 & -9.6 & 8.0 & 0.60 & 0.65 & 0.68 & -11.5 & 7.7 \\
\hline stn109 & 19.4 & 0.75 & 0.86 & 0.93 & -10.9 & 6.8 & 0.77 & 0.86 & 0.93 & -11.6 & 6.4 \\
\hline $\operatorname{stn} 435$ & 5.8 & 0.19 & 0.22 & 0.22 & -2.7 & 6.5 & 0.33 & 0.55 & 0.74 & -4.0 & 5.7 \\
\hline $\operatorname{stn} 434$ & -0.9 & 0.57 & 0.68 & 0.85 & -11.3 & 3.9 & 0.51 & 0.65 & 0.82 & -13.4 & 4.0 \\
\hline $\operatorname{stn} 175$ & -1.3 & 0.34 & 0.24 & 0.35 & -1.8 & 5.5 & 0.43 & 0.34 & 0.27 & -2.9 & 5.0 \\
\hline $\operatorname{stn} 219$ & -5.9 & 0.61 & 0.74 & 0.89 & -3.1 & 6.5 & 0.67 & 0.76 & 0.90 & -4.3 & 6.2 \\
\hline $\operatorname{stn} 328$ & -8.0 & 0.57 & 0.66 & 0.94 & 2.8 & 7.8 & 0.64 & 0.74 & 0.97 & 1.3 & 7.4 \\
\hline $\operatorname{stn} 191$ & -14.2 & 0.62 & 0.64 & 0.74 & -13.3 & 5.4 & 0.68 & 0.70 & 0.81 & -15.0 & 4.8 \\
\hline $\operatorname{stn} 438$ & -18.1 & 0.69 & 0.77 & 0.86 & -12.3 & 6.1 & 0.70 & 0.77 & 0.86 & -15.4 & 5.7 \\
\hline $\operatorname{stn} 436$ & -21.1 & 0.54 & 0.66 & 0.78 & -1.2 & 7.0 & 0.69 & 0.76 & 0.84 & -6.5 & 5.7 \\
\hline $\operatorname{stn} 394$ & -37.7 & 0.33 & 0.36 & 0.59 & 0.3 & 7.9 & 0.54 & 0.71 & 0.79 & -2.1 & 5.8 \\
\hline $\operatorname{stn} 256$ & -45.0 & 0.43 & 0.45 & 0.62 & -4.6 & 6.4 & 0.64 & 0.72 & 0.73 & -6.3 & 3.8 \\
\hline stn029 & -54.5 & 0.36 & 0.53 & 0.75 & -1.7 & 7.7 & 0.63 & 0.70 & 0.69 & -2.7 & 5.0 \\
\hline $\operatorname{stn} 233$ & -64.2 & 0.33 & 0.66 & 0.75 & -2.7 & 9.2 & 0.52 & 0.69 & 0.79 & -2.1 & 7.0 \\
\hline stn101 & -69.0 & 0.26 & 0.41 & 0.67 & -1.4 & 9.1 & 0.42 & 0.46 & 0.63 & -0.9 & 6.3 \\
\hline
\end{tabular}

$\mathrm{O}_{3}$ is larger in the tropics and subtropics (Liu et al., 2005, 2006). Furthermore, the comparison between modelled and observed tropical UTLS $\mathrm{O}_{3}$ showed that the comparison was not as good as outside of the tropics and subtropics. Hence, there is room for improvement of the performance of simulated $\mathrm{O}_{3}$ at tropical latitudes, where the $\mathrm{O}_{3}$ profile assimilation leads to improvements in the modelled UTLS columns.

\subsection{Evaluation of TM5 assimilated TTOC with sonde observations}

We only very briefly discuss the differences in TTOC's for the TM5 simulations with and without assimilation of GOME $\mathrm{O}_{3}$ profiles. Here, a consistent picture arises from Table 2. Correlations between model results and sonde measurements are nearly always better for the simulation without assimilation compared to the simulation with assimilation.
This is reflected in the rms differences, which are better for nearly all locations. On the other hand, the bias between model results and sonde measurements improves for nearly all locations when GOME $\mathrm{O}_{3}$ profiles are assimilated. Apparently the effect of assimilation of GOME $\mathrm{O}_{3}$ profiles is the increasing variability in modelled TTOC's, while at the same time the average TTOC's improve.

\subsection{Comparing result from the free and assimilation runs}

Figure 3 shows the UTLS ozone columns for the four stations presented in Fig. 2 for both the free TM5 simulation (grey) and the TM5 assimilation run (black) as well as the differences in UTLS ozone (lower panels). For all four stations there is a high correlation between the free run and assimilation results. However, for the two mid-latitude stations 

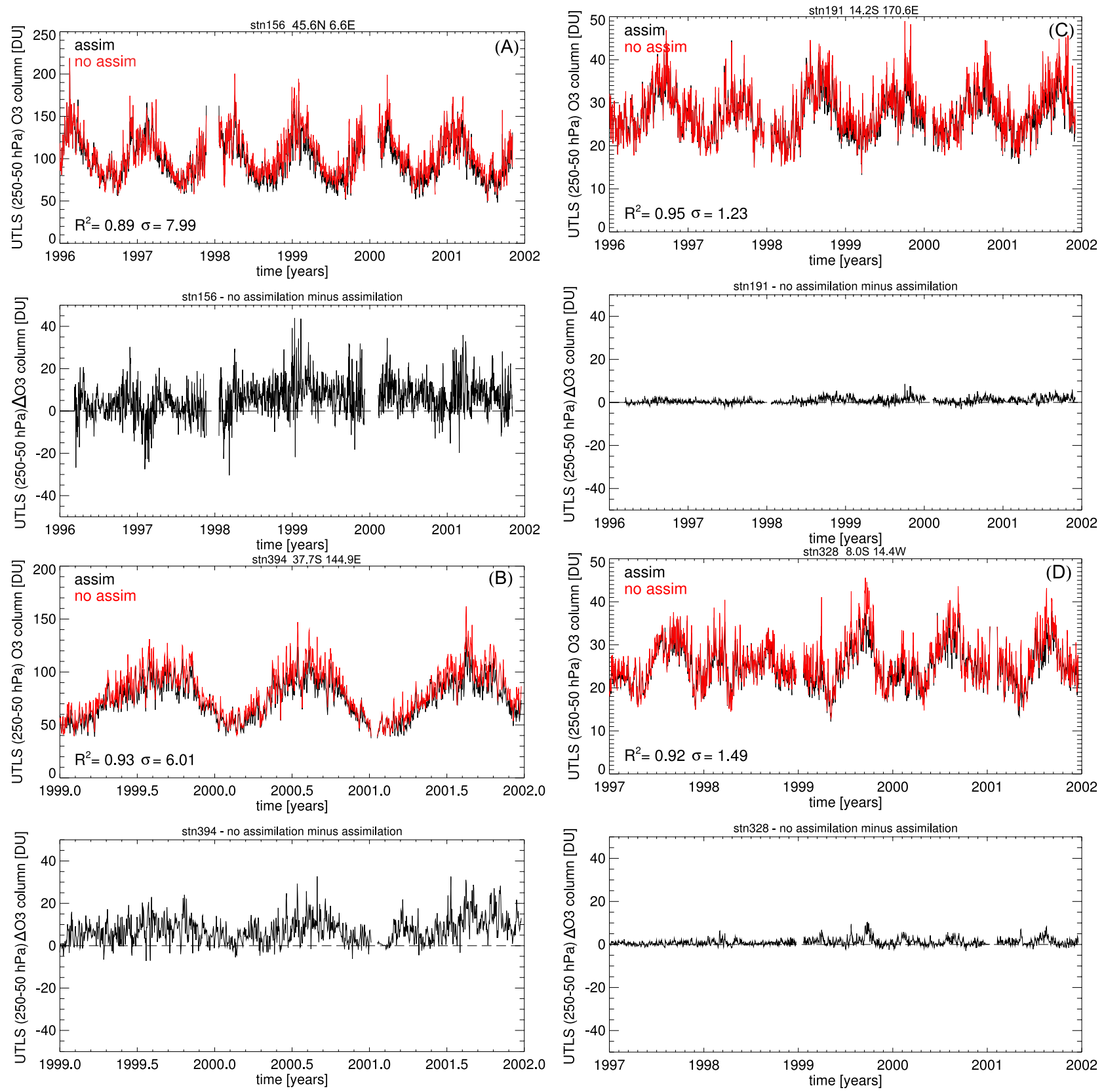

Fig. 3. As Fig. 2 but for the free run (red) and assimilation (black) UTLS $\mathrm{O}_{3}$ columns only. The lower panels show the differences in UTLS $\mathrm{O}_{3}$ columns between both runs. Indicated in the figures are also the correlations between both runs $\left(R^{2}\right)$ and the root-mean-square of the differences between both runs $(\sigma$; in DU). Table S3 provides a full overview of these statistics for all sonde locations in Table S0: http://www.atmos-chem-phys.net/9/8105/2009/acp-9-8105-2009-supplement.pdf.

Payerne, (stn156; Fig. 3a) and Broad Meadows (stn394; Fig. 3b) the differences between both can be tens of DU, which is highly relevant if the typical TTOC ranges between 20-50 DU. For the two tropical stations differences are very small. The CARIOLLE scheme is well capable of reproducing the stratospheric tropical ozone distribution, which is to a large extent determined by seasonal variations in solar radiation and should be represented very well by the ozone climatology that is based on multi-year observations. The GOME ozone profiles therefore cannot add much information to tropical stratospheric ozone, and as a result differences between the free run and assimilation are negligible. 

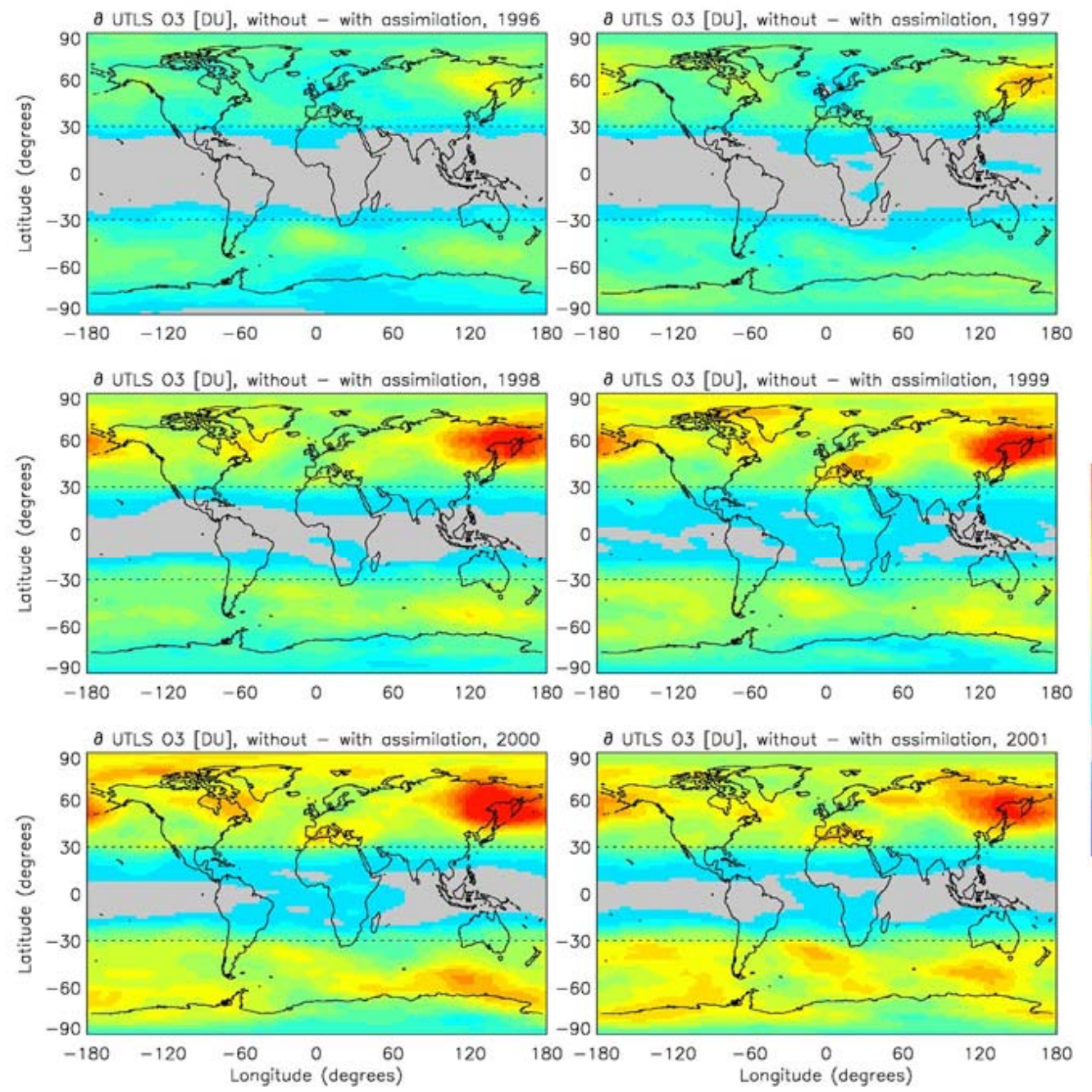

Fig. 4. Annual mean UTLS $(250-50 \mathrm{hPa}) \mathrm{O}_{3}$ partial column differences [DU] between the free running TM5 model simulation and the TM5 GOME $\mathrm{O}_{3}$ profile assimilation run for every single year from 1996 (upper left) to 2001 (lower right). A positive difference means that the modeled $\mathrm{O}_{3}$ column for the simulation without assimilation is larger than the modeled $\mathrm{O}_{3}$ column for the simulation with assimilation. Values between -1 and +1 DU are indicated in grey.

\subsection{Effect of $\mathrm{O}_{3}$-profile assimilation on the 6-year free-running UTLS $\mathrm{O}_{3}$}

Chemistry-transport models show a general tendency to overestimate the residual stratospheric circulation, i.e. too fast transport from the tropics to middle and high latitudes (Douglass et al., 2003), also called the overstrong meridional circulation (Stajner et al., 2008). The effect of this overly strong circulation is a gradual accumulation of stratospheric $\mathrm{O}_{3}$ outside of the tropics and subtropics, as stratospheric $\mathrm{O}_{3}$ is produced in the tropics and slowly transport to higher latitudes where destruction occurs. This effect has also been reported for TM5 (de Laat et al., 2007), but can be countered by assimilation of stratospheric $\mathrm{O}_{3}$ profiles (Stajner et al., 2008).
Figure 4 shows the annual mean differences for all years from 1996 to 2001 for TM5 UTLS ozone without and with assimilation. Differences in extra-tropical UTLS $\mathrm{O}_{3}$ gradually increase year by year, while tropical UTLS $\mathrm{O}_{3}$ differences are close to zero. This spatial pattern is typical for the overstrong meridional stratospheric circulation in chemistrytransport models (de Laat et al., 2007). It also shows that the assimilation - on average - counters this $\mathrm{O}_{3}$ build up. It explains why biases in the model-sonde UTLS $\mathrm{O}_{3}$ improve when $\mathrm{O}_{3}$ profiles are assimilated despite worse rms differences (Table 1). The overstrong circulation is a long-term process affecting the average ozone whereas the assimilation affects individual days and profiles, therefore short synoptictime variability and thus rms differences. Summarizing, we find that the effect of assimilating GOME $\mathrm{O}_{3}$ profiles counteracts the stratospheric $\mathrm{O}_{3}$ model drift and thus improves the 
analysis with regard to the long term variations in UTLS $\mathrm{O}_{3}$, although it does not correct the model transport deficiencies due to the ECMWF meteorological data.

\subsection{Evaluation of TORA residuals with $\mathrm{O}_{3}$ sondes}

The comparison of sonde measurements and modelled $\mathrm{O}_{3}-$ either without or with assimilation of GOME observations showed that there are still large differences on a day-to-day basis in tropospheric and lower stratospheric $\mathrm{O}_{3}$. Furthermore, the assimilation of the GOME $\mathrm{O}_{3}$ profiles gave only limited improvements in day-to-day UTLS $\mathrm{O}_{3}$ at tropical latitudes and mainly degraded UTLS $\mathrm{O}_{3}$ at mid-latitudes. Since it is crucial to be able to separate stratosphere from troposphere, the presence of biases and the limited improvement - if any - due to the assimilation may not have lead to an improvement in estimating the stratospheric $\mathrm{O}_{3}$ column.

Figure 5 shows the TORA residuals from the GDP v4.1 total $\mathrm{O}_{3}$ columns minus the assimilated stratospheric $\mathrm{O}_{3}$ columns and the corresponding $\mathrm{O}_{3}$ sonde TTOC's (when available) for two locations also shown in Fig. 2 (Payerne and Ascension). The comparison for Payerne shows that variations in the individual TORA residuals are unrealistically large compared to the sonde observations. This type of behaviour is representative for all mid-latitude locations. For the tropical location the comparison looks better although there are only a limited number of collocations with sondes available for validation.

The monthly means for the TORA residuals and $\mathrm{O}_{3}$ sonde TTOC's show similar seasonal cycles, but the seasonal cycles in the residuals are two to three times larger than observed. Note that using total column observations from a different algorithm (TOGOMI instead of GDP v4.1) yielded similar results, as did the use of the model simulation without assimilation, which is unsurprising given earlier findings about the quality of the free-running TM5 simulation. Furthermore, it should be noted that many earlier studies have shown that within the tropics other - simpler - residual methods gave satisfactory results (see Tarasick and Slater, 2008, for an overview). In addition, Liu et al. (2006) have shown that directly measured tropical TTOC's from $\mathrm{GOME} \mathrm{O}_{3}$ profiles agreed very well with model simulations for two regions over Indonesia and the equatorial Pacific. A visual inspection of tropospheric $\mathrm{O}_{3}$ observations directly derived from the GOME OPERA $\mathrm{O}_{3}$ profiles used in this study (not shown) revealed a remarkable agreement with the satellite measurements for the two regions presented in Liu et al. (2006).

Table 3 shows the statistical evaluation of the TORA residuals. Note that the number of collocations with sonde observations was reduced compared to previous model-sonde comparisons due to fewer GOME GDP total column observations. The overall picture is that, with only a few exceptions, correlations and rms differences between the TORA residuals and $\mathrm{O}_{3}$ sondes degrade - often significantly $(>0.1$ decrease in correlation; $>5 \mathrm{DU}$ increase in $\sigma$ ) - compared
Table 3. As Table 2 but for the TORA residuals, i.e. total $\mathrm{O}_{3}$ column observations minus stratospheric $\mathrm{O}_{3}$ columns from the TM5 CARIOLLE assimilation of GOME OPERA $\mathrm{O}_{3}$ profiles. For the total $\mathrm{O}_{3}$ columns the GOME GDP v4.1 product was used. Climatological monthly mean statistics were not calculated due to insufficient sonde collocations for most sonde stations. Locations are ordered according to their latitude. The statistics shown here are the standard Pearsons correlation coefficient $(R)$ for the six year period 1996-2001, the correlation for monthly means $(R m)$, the average bias $(\Delta$; sonde-model) and the root-mean-square differences $(\sigma)$. Biases and differences are in Dobson Units (DU; $2.69 \times 10^{18}$ molecules $\mathrm{cm}^{2}$ ). The bold numbers indicate the better statistical values for the comparison of sonde measurements and model results with assimilation compare to without assimilation. "Better" refers to larger correlations, smaller biases and smaller rms differences. Stations shown in Fig. 3 are indicated in grey. Statistics for all available sonde stations can be found in supplementary Table S1: http://www.atmos-chem-phys.net/9/8105/2009/ acp-9-8105-2009-supplement.pdf.

\begin{tabular}{|c|c|c|c|c|c|}
\hline \multirow[b]{2}{*}{ Station } & \multirow[b]{2}{*}{ lat } & \multicolumn{4}{|c|}{$\begin{array}{c}\text { TORA residual } \\
\text { GDP v4.1 minus TM5/GOME }\end{array}$} \\
\hline & & $R$ & $R m$ & $\Delta$ & $\sigma$ \\
\hline $\operatorname{stn} 315$ & 80.0 & -0.03 & -0.05 & 0.1 & 38.7 \\
\hline $\operatorname{stn} 089$ & 78.9 & 0.03 & 0.08 & 8.4 & 38.9 \\
\hline $\operatorname{stn} 024$ & 74.7 & -0.10 & 0.06 & -10.9 & 31.9 \\
\hline $\operatorname{stn} 262$ & 67.4 & -0.38 & -0.64 & -0.2 & 20.4 \\
\hline $\operatorname{stn} 043$ & 60.1 & 0.02 & 0.06 & -7.8 & 35.8 \\
\hline $\operatorname{stn} 077$ & 58.7 & -0.31 & -0.34 & -17.2 & 25.9 \\
\hline $\operatorname{stn} 316$ & 52.1 & 0.06 & 0.08 & -9.4 & 24.3 \\
\hline $\operatorname{stn} 156$ & 46.5 & 0.25 & 0.29 & -1.4 & 25.2 \\
\hline $\operatorname{stn} 012$ & 43.1 & 0.27 & 0.23 & -15.1 & 25.6 \\
\hline $\operatorname{stn} 107$ & 37.8 & 0.24 & 0.39 & -1.4 & 21.3 \\
\hline $\operatorname{stn} 190$ & 26.2 & 0.34 & 0.24 & -2.7 & 15.2 \\
\hline $\operatorname{stn} 109$ & 19.4 & 0.19 & 0.30 & 9.6 & 14.9 \\
\hline $\operatorname{stn} 435$ & 5.8 & -0.21 & -0.18 & -13.6 & 7.4 \\
\hline $\operatorname{stn} 434$ & -0.9 & 0.47 & 0.44 & -4.5 & 14.3 \\
\hline $\operatorname{stn} 175$ & -1.3 & 0.24 & 0.24 & 3.0 & 12.4 \\
\hline $\operatorname{stn} 219$ & -5.9 & 0.26 & 0.24 & -12.0 & 9.6 \\
\hline $\operatorname{stn} 328$ & -8.0 & 0.37 & 0.41 & -11.4 & 12.1 \\
\hline $\operatorname{stn} 191$ & -14.2 & 0.40 & 0.44 & -8.9 & 13.0 \\
\hline $\operatorname{stn} 438$ & -18.1 & 0.62 & 0.61 & -17.9 & 18.7 \\
\hline $\operatorname{stn} 436$ & -21.1 & 0.42 & 0.41 & -12.3 & 13.5 \\
\hline $\operatorname{stn} 394$ & -37.7 & 0.25 & 0.25 & 3.0 & 20.6 \\
\hline $\operatorname{stn} 256$ & -45.0 & & .30 & -0.7 & 28.6 \\
\hline $\operatorname{stn} 029$ & -54.5 & -0.28 & -0.48 & 56.8 & 46.5 \\
\hline $\operatorname{stn} 233$ & -64.2 & -0.21 & -0.39 & 53.1 & 46.7 \\
\hline \multirow[t]{2}{*}{$\operatorname{stn} 101$} & -69.0 & -0.30 & -0.69 & 46.1 & 44.3 \\
\hline & & \multicolumn{4}{|c|}{$\begin{array}{c}\text { TORA residual } \\
\text { GDP v4.1 minus TM5/GOME }\end{array}$} \\
\hline Station & lat & $R$ & $R m$ & $\Delta$ & $\sigma$ \\
\hline $\operatorname{stn} 315$ & 80.0 & -0.03 & -0.05 & 0.1 & 38.7 \\
\hline $\operatorname{stn} 089$ & 78.9 & 0.03 & 0.08 & 8.4 & 38.9 \\
\hline stn024 & 74.7 & -0.10 & 0.06 & -10.9 & 31.9 \\
\hline $\operatorname{stn} 262$ & 67.4 & -0.38 & -0.64 & -0.2 & 20.4 \\
\hline $\operatorname{stn} 043$ & 60.1 & 0.02 & 0.06 & -7.8 & 35.8 \\
\hline $\operatorname{stn} 077$ & 58.7 & -0.31 & -0.34 & -17.2 & 25.9 \\
\hline $\operatorname{stn} 316$ & 52.1 & 0.06 & 0.08 & -9.4 & 24.3 \\
\hline $\operatorname{stn} 156$ & 46 & & 0.29 & -1.4 & 25.2 \\
\hline $\operatorname{stn} 012$ & 43.1 & 0.27 & 0.23 & -15.1 & 25.6 \\
\hline $\operatorname{stn} 107$ & 37.8 & 0.24 & 0.39 & -1.4 & 21.3 \\
\hline $\ln 190$ & 26.2 & & 0.38 & -3.8 & 16.3 \\
\hline $\operatorname{stn} 109$ & 19.4 & 0.35 & 0.42 & -10.6 & 17.2 \\
\hline $\operatorname{stn} 435$ & 5.8 & 0.05 & -0.05 & -1.4 & 14.2 \\
\hline $\operatorname{stn} 434$ & -0.9 & 0.46 & 0.40 & -11.0 & 10.6 \\
\hline $\operatorname{stn} 175$ & -1.3 & 0.47 & 0.44 & -4.5 & 14.3 \\
\hline $\operatorname{stn} 219$ & -5.9 & 0.59 & 0.74 & -5.6 & 11.7 \\
\hline $\operatorname{stn} 328$ & -8.0 & 0.47 & 0.47 & -3.7 & 12.3 \\
\hline $\operatorname{stn} 191$ & -14.2 & 0.37 & 0.41 & -11.4 & 12.1 \\
\hline $\operatorname{stn} 438$ & -18.1 & 0.39 & 0.45 & -15.2 & 17.6 \\
\hline $\operatorname{stn} 436$ & -21.1 & 0.62 & 0.61 & -17.9 & 18.7 \\
\hline $\operatorname{stn} 394$ & -37.7 & 0.25 & 0.25 & 3.0 & 20.6 \\
\hline $\operatorname{stn} 256$ & -45.0 & & 0.34 & -11.6 & 23.9 \\
\hline $\operatorname{stn} 029$ & -54.5 & 0.18 & 0.30 & -0.7 & 28.6 \\
\hline $\operatorname{stn} 233$ & -64.2 & -0.28 & -0.48 & 56.8 & 46.5 \\
\hline $\operatorname{stn} 101$ & -69.0 & -0.21 & -0.39 & 53.1 & 46.7 \\
\hline
\end{tabular}

Atmos. Chem. Phys., 9, 8105-8120, 2009 

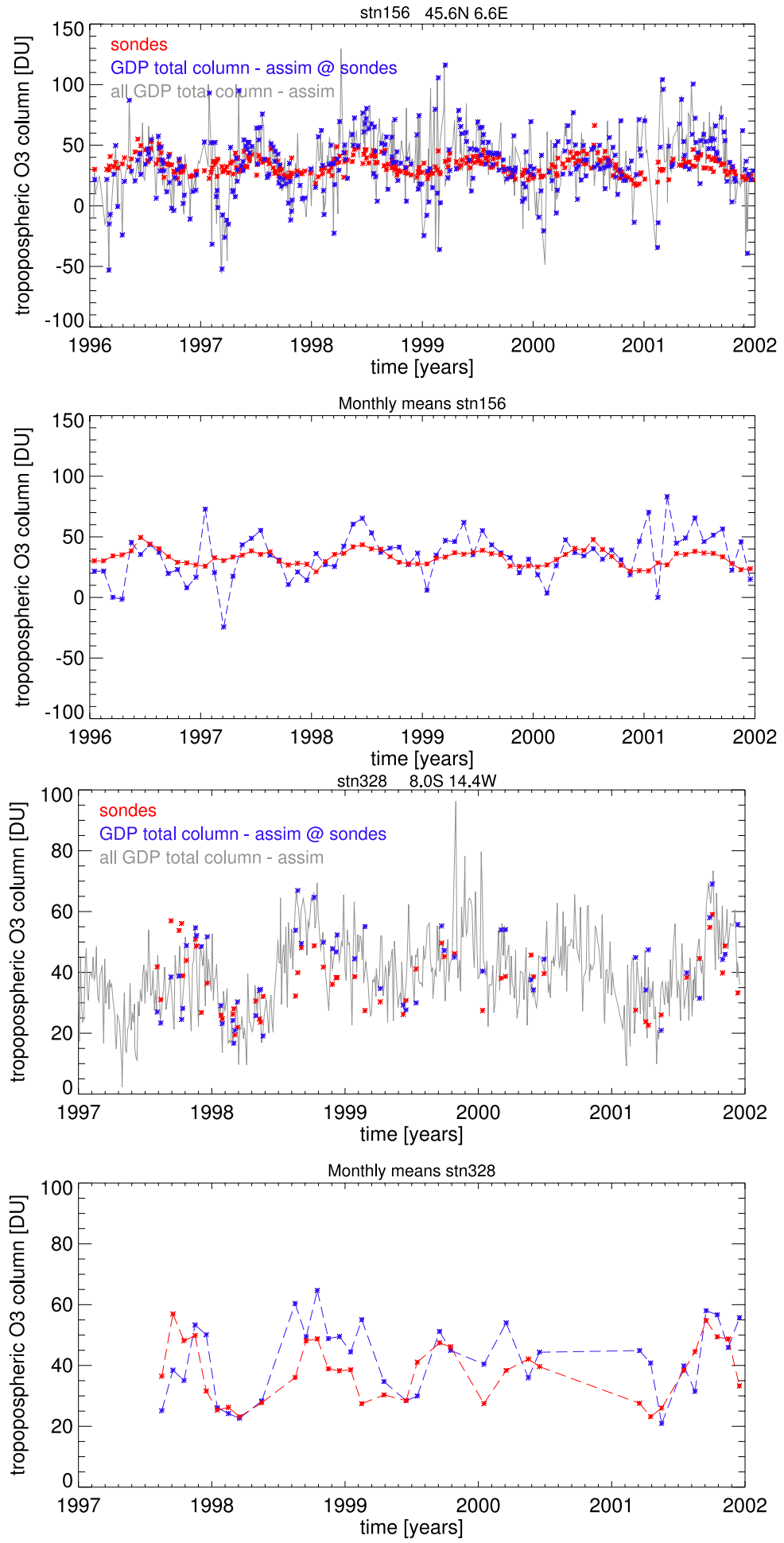

Fig. 5. Comparison of TORA residual tropospheric $\mathrm{O}_{3}$ columns (total $\mathrm{O}_{3}$ column (GDP v4.1 GOME) minus assimilated stratospheric $\mathrm{O}_{3}$ column) with WOUDC $\mathrm{O}_{3}$ sondes for Payerne, Switzerland (stn156) and Ascension Island (stn328) (see Fig. 1 and supplementary Table S0 for location details: http://www.atmos-chem-phys.net/9/8105/2009/acp-9-8105-2009-supplement.pdf). For both locations, the upper panel shows the daily observed sonde (red) and TORA residual (blue: collocated with sondes; grey: all columns). The lower panel for each location shows the corresponding monthly means. 

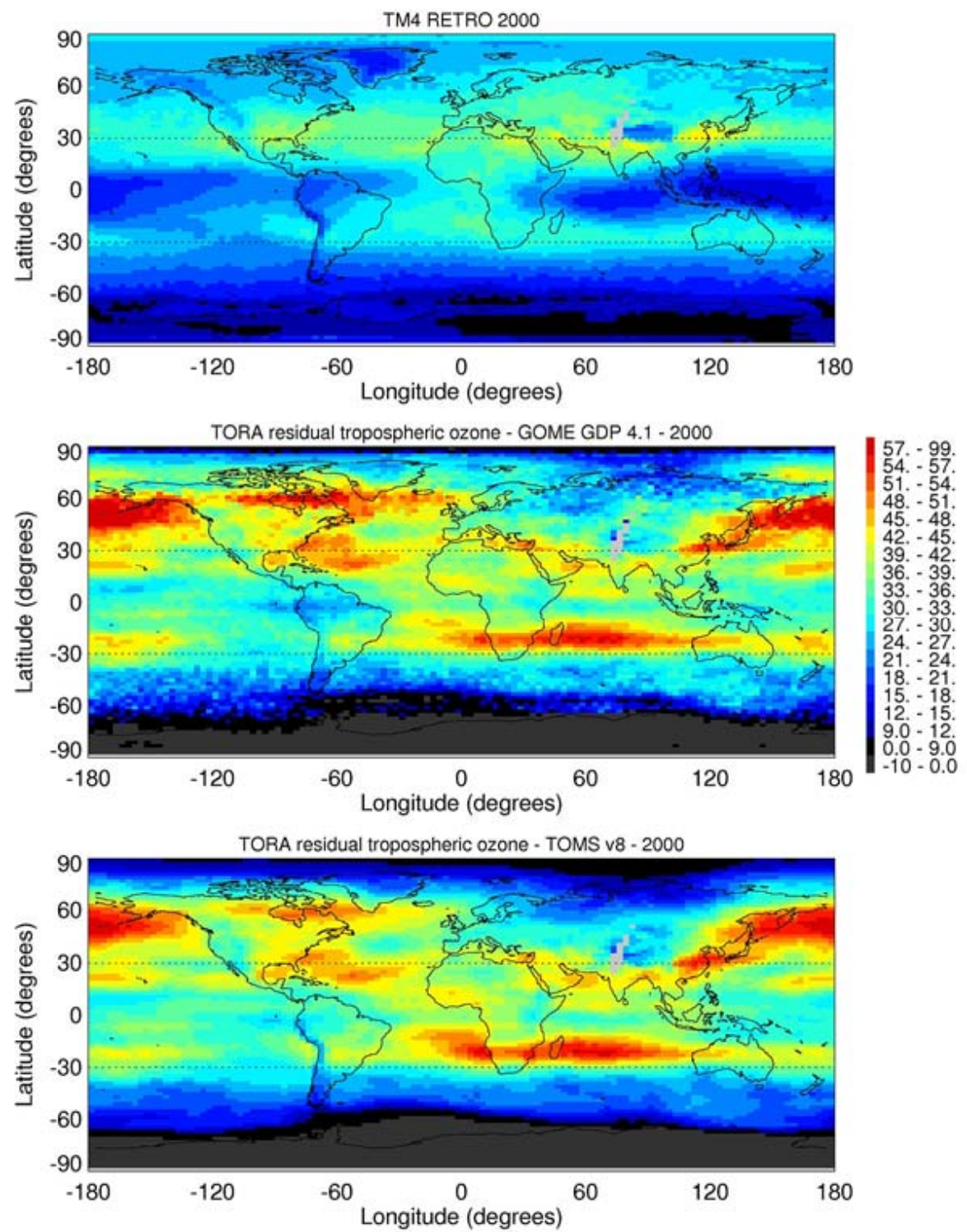

Fig. 6. Global mean total tropospheric $\mathrm{O}_{3}$ columns (TTOC's) for the year 2000 in DU. Upper panel: TM4 simulated TTOC from the RETROproject reanalysis simulations (RETRO, 2007). Middle panel: TORA O 3 residuals from GDP v4.1 total $\mathrm{O}_{3}$ columns minus TM5 GOME assimilated stratospheric $\mathrm{O}_{3}$ columns. Lower panel: as middle panel but using TOMS v8 instead of GOME GDP v4.1 total $\mathrm{O}_{3}$ columns

to the statistics of the modelled tropospheric ozone columns and $\mathrm{O}_{3}$ sonde measurements as presented in Table 2. Nevertheless, for a number of locations the bias still improves, showing that the assimilation increases the "noise" in the residual but not the average differences. At high southern latitudes very large biases of $50 \mathrm{DU}$ or more occur due to the fact that neither the model simulation nor the GOME $\mathrm{O}_{3}$ profiles could provide realistic ozone hole $\mathrm{O}_{3}$ profiles. In addition, opposite to the comparisons between modelled and measured TTOC and UTLS columns, the correlations do not improve for the TORA residuals going from individual columns to monthly mean columns $\left(R_{m}\right.$, Table 3$)$.
Figure 6 shows a comparison of the mean TORA residuals using respectively GOME GDP - middle panel - and TOMS - lower panel - v8 total columns for the year 2000. For comparison we added the TTOC from a TM4 chemistry-transport model simulation using a full tropospheric chemistry scheme and realistic emission estimates (RETRO, 2007). The TORA residuals using the model simulations with and without assimilation are 10-20 DU larger than the full-chemistry TM4 modelled TTOC's and show some realistic features, for example the biomass burning $\mathrm{O}_{3}$ maximum over the equatorial Atlantic, high TTOC values around the subtropical jets $\left(30^{\circ} \mathrm{N} / \mathrm{S}\right)$ and low columns over the equatorial Pacific. 
However, small and even negative residuals are found around Antarctica due to the lack of an ozone hole in the TM5 model simulations as well as in the GOME $\mathrm{O}_{3}$ profiles. Although results might appear realistic at mid and high latitudes, given the large amount of noise for individual TORA residuals it remains questionable whether the spatial variations of the residuals contains much useful information. The spatial coherence of residuals from either GOME or TOMS total columns is an indication that the lack of useful information is related to the (assimilated) stratospheric $\mathrm{O}_{3}$ column whose spatial resolution insufficiently accurate for this purpose - and not a problem with the total column observations. Other years yielded similar results in terms of representativeness of the TORA residuals and coherence by using either GOME or TOMS total $\mathrm{O}_{3}$ columns.

\section{Discussion and conclusions}

This paper presents an evaluation of level-2 residual tropospheric $\mathrm{O}_{3}$ columns derived from subtracting free-run and assimilated model stratospheric $\mathrm{O}_{3}$ columns from total column observations, the so-called TORA method. TORA residuals have been calculated using GOME $\mathrm{O}_{3}$ profile and GOME total $\mathrm{O}_{3}$ column observations for the six year period 19962001.

The comparison of model simulations without assimilation for the UTLS region (partial $\mathrm{O}_{3}$ column between 250 and $50 \mathrm{hPa}$ ) with independent $\mathrm{O}_{3}$ sonde observations shows that the TM5 model with the CARIOLLE chemistry scheme produces realistic $\mathrm{O}_{3}$ variations in the UTLS, both on short day-to-day as well as longer seasonal timescales, although for the tropics and subtropics some tropospheric biases occur because of the use of the zonal-mean tropospheric $\mathrm{O}_{3}$ climatology. The agreement improves for monthly and climatological means. The results also show that the rms differences are rather good for middle and high latitudes.

When assimilating GOME $\mathrm{O}_{3}$ profiles in the TM5 model simulation the UTLS biases are reduced in comparison to $\mathrm{O}_{3}$ sonde data. Within the tropics and subtropics correlations and rms differences between model results and $\mathrm{O}_{3}$ sonde observations also improve slightly. On the other hand, correlations and rms differences outside of the tropics and subtropics degrade albeit not very significantly. This result can be explained as follows: mid-latitude stratospheric $\mathrm{O}_{3}$ in TM5 has a tendency to slowly increase over years, an effect that is related to the overstrong stratospheric meridional circulation generally present in chemistry-transport models driven by off-line analysed meteorological fields (Douglass et al., 2003). The overstrong circulation pumps too much $\mathrm{O}_{3}$ from the tropical stratosphere $\left(\mathrm{O}_{3}\right.$ production) to the stratosphere at higher latitudes where $\mathrm{O}_{3}$ accumulates as destruction remains similar but transport increases. The assimilation of GOME $\mathrm{O}_{3}$ profiles counters this effect, reducing the bias in average UTLS $\mathrm{O}_{3}$, although it does not correct the model transport deficiencies due to the ECMWF meteorological data.

At the same time the increase in rms differences is likely related to the very large footprint of the GOME pixel $(960 \times 80 \mathrm{~km})$, which is larger than the typical correlation length of upper tropospheric $(\sim 100 \mathrm{~km})$ and lower stratospheric $(\sim 300-400 \mathrm{~km}) \mathrm{O}_{3}$ variations. Hence, the assimilation introduces errors in single model $\mathrm{O}_{3}$ profiles as much as it improves the average representation of UTLS $\mathrm{O}_{3}$. Additional errors may be introduced by retrieval uncertainties, including the vertical smoothing of the GOME $\mathrm{O}_{3}$ profiles and instrumental errors. The latter are not analyzed here, but are subject of another paper (Mijling et al., submitted, 2009).

Within the tropics and subtropics the TORA residuals appear realistic and the assimilation helped to slightly reduce the bias in modelled UTLS $\mathrm{O}_{3}$ compared to ozone sondes. Outside of the tropics and subtropics the day-to-day variations in the individual residuals are much larger than the observed variability - even yielding negative values. Using both GOME and TOMS total column observations results in very similar spatial patterns of the average residuals, showing that the too large day-to-day variations are not related to the total column observations but to the (assimilated) stratospheric $\mathrm{O}_{3}$ columns. The tropical stratospheric column shows much less variability than mid-latitude stratospheric columns, providing an additional indication that the GOME $\mathrm{O}_{3}$ profile observations are too coarse to fully capture UTLS $\mathrm{O}_{3}$ variability outside of the tropics and subtropics. Given the results from the validation with sonde observations it is not very likely that the spatial variations in the annual means and the interannual variability contain valuable information outside of the tropics and subtropics.

In summary, added value of the assimilation of GOME $\mathrm{O}_{3}$ profiles in TM5 is found for long term multi-annual changes in modelled stratospheric $\mathrm{O}_{3}$, which due to the overstrong stratospheric circulation in TM5 tends to accumulate $\mathrm{O}_{3}$ in the stratosphere outside of the tropics and subtropics. The assimilation clearly counters this effect. In the tropics and subtropics there is little added value from the assimilation. Variability of stratospheric $\mathrm{O}_{3}$ is limited and - unsurprisingly - well captured by the CARIOLLE scheme which includes a stratospheric $\mathrm{O}_{3}$ climatology that leads to realistic seasonal variations in modelled tropical stratospheric $\mathrm{O}_{3}$. Fortunately, the limited variability of tropical stratospheric $\mathrm{O}_{3}$ enables other methods for determining the tropospheric $\mathrm{O}_{3}$ column in the tropics and subtropics - either direct from $\mathrm{O}_{3}$ profile observations or by indirect methods like cloud slicing. Outside of the tropics and subtropics, the assimilation has no clear effect on short timescales as most variability occurs in the UTLS region as the spatial scales of this variability are considerably smaller than the footprint of the GOME $\mathrm{O}_{3}$ profile observations.

Our results clearly point to the direction the TORA methodology can be improved in order to obtain realistic residuals outside of the tropics and subtropics. The spatial 
resolution of the model should be increased to at least $1^{\circ} \times 1^{\circ}$, and preferably better, so that mid-latitude UTLS $\mathrm{O}_{3}$ variations can be more realistically simulated. Realistically means that the model resolution should be smaller than the empirically established correlation length of UTLS variations, which is about $100 \mathrm{~km}$ or $1^{\circ}$ for the upper troposphere according to Sparling et al. (2006). In addition, the observations that are assimilated should preferably have a footprint that is at least of similar size as the model simulation on $1^{\circ} \times 1^{\circ}$, and also preferably smaller.

Schoeberl et al. (2007) presented results for a similar-butdifferent methodology, similar in a sense that the method also assimilates observed $\mathrm{O}_{3}$ profiles, but different in sense that a different assimilation approach (isentropic transport along trajectories) and different observations were used $\left(\mathrm{O}_{3}\right.$ profiles from the Microwave Limb Sounder). Nevertheless, with a better spatial resolution $-1.25^{\circ} \times 1^{\circ}$ longitude-latitude Schoeberl et al. (2007) derived realistic $\mathrm{O}_{3}$ variations. These results suggest that for the TORA methodology a smaller spatial grid than the current setup will improve results. This improvement is likely related to the spatial extent of $\mathrm{O}_{3}$ structures in the UTLS region, which suggests that $\mathrm{O}_{3}$ profile observations with a smaller spatial footprint than the GOME $\mathrm{O}_{3}$ profiles may be beneficial as well. A considerable improvement in $\mathrm{O}_{3}$ profile quality and accuracy has been reported for GOME-2 $\mathrm{O}_{3}$ profiles compared to GOME $\mathrm{O}_{3}$ profiles (van Peet et al., 2009). At the same time GOME- $2 \mathrm{O}_{3}$ profiles can be retrieved with a small spatial footprint of $80 \times 40 \mathrm{~km}$. As an alternative $\mathrm{OMI} \mathrm{O}_{3}$ profiles could be used which have a similar spatial footprint $-48 \times 13 \mathrm{~km}$.

We conclude that the TORA methodology to derive tropospheric $\mathrm{O}_{3}$ columns by subtracting best-estimate stratospheric $\mathrm{O}_{3}$ columns from total $\mathrm{O}_{3}$ column observations is valuable for past and present-day satellite observations, and using GOME total $\mathrm{O}_{3}$ column and $\mathrm{O}_{3}$ profile observations provides realistic tropospheric $\mathrm{O}_{3}$ columns for tropical latitudes. Outside of the tropics and subtropics, accurately estimating the tropospheric $\mathrm{O}_{3}$ column is hampered by the too large ground pixel of the GOME $\mathrm{O}_{3}$ profile observations and possible insufficient accuracy of the $\mathrm{O}_{3}$ profile observations as well as a too large horizontal resolution of the TM5 assimilation model. Hence, the use of GOME of GOME UV-VIS nadir $\mathrm{O}_{3}$ profiles in combination with the spatial resolution of the model does not result in satisfactory residual tropospheric $\mathrm{O}_{3}$ columns.

Recommendations for future application of the TORA methodology are to use $\mathrm{O}_{3}$ profile observations with a smaller spatial footprint - preferably $1^{\circ} \times 1^{\circ}$ degrees or smaller - and a better horizontal resolution of the assimilation model - preferably $1^{\circ} \times 1^{\circ}$ degrees or smaller. UV-VIS $\mathrm{O}_{3}$ profile observations with the required spatial footprint are becoming available from the GOME-2 and OMI instruments, which in the near future will be used for applying the TORA methodology.
Acknowledgements. This research was funded by the Dutch national "Gebruikers Ondersteuning (GO)" program (National Research Council, NWO, National Institute for Space Research, SRON). The authors thank the WOUDC for maintaining their database and freely providing $\mathrm{O}_{3}$ sonde observations, and T. van Noije (KNMI) for providing TM4 RETRO chemistrytransport model results.

Edited by: M. Van Roozendael

\section{References}

Balis, D., Lambert, J.-C., van Roozendael, M., Spurr, R., Loyola, D., Livschitz, Y., Valks, P., Amiridis, V., Gerard, P., Granville, J., and Zehner, C.: Ten years of GOME/ERS-2 total ozone data: the new GOME Data Processor (GDP) Version 4: II, Groundbased validation and comparisons with TOMS V7/V8, J. Geophys. Res., 112, D07307, doi:10.1029/2005JD006376, 2007.

Bhartia, P. K.: TOMS v8 Algorithm Theoretical Basis Document (ATBD), http://toms.gsfc.nasa.gov/version8/v8toms_atbd. pdf, last access: 1 September 2009, 2004.

Brasseur, G. P., Orlando, J. J., and Tyndall, G. S.: Atmospheric Chemistry and Global Change, Oxford Univ. Press, New York, 1999.

Bregman, B., Segers, A., Krol, M., Meijer, E., and van Velthoven, P.: On the use of mass-conserving wind fields in chemistrytransport models, Atmos. Chem. Phys., 3, 447-457, 2003, http://www.atmos-chem-phys.net/3/447/2003/.

Cariolle, D. and Deque, M.: Southern Hemisphere Medium-Scale Waves and Total Ozone Disturbances in a Spectral General Circulation Model, J. Geophys. Res., 91, 10825-10846, 1986.

Cariolle, D. and Teyssèdre, H.: A revised linear ozone photochemistry parameterization for use in transport and general circulation models: multi-annual simulations, Atmos. Chem. Phys., 7, 2183-2196, 2007, http://www.atmos-chem-phys.net/7/2183/2007/.

de Clercq, C. and Lambert, J.-C.: GEOSP-GOME, geophysical information content and validation of ERS-2 GOME ozone profile data records, ESA Technical Note TN-IASB-GOME1-CHEOSP01-1/B, 20 December 2007.

de Laat, A. T. J., Aben, I., and Roelofs, G. J.: A model perspective on total tropospheric $\mathrm{O}_{3}$ column variability and implications for satellite observations, J. Geophys. Res., 110, D13303, doi: 10.1029/2004JD005264, 2005.

de Laat, A. T. J., Landgraf, J., Aben, I., Hasekamp, O., and Bregman, B.: Validation of Global Ozone Monitoring Experiment ozone profiles and evaluation of stratospheric transport in a global chemistry transport model, J. Geophys. Res., 112, D05301, doi: 10.1029/2005JD006789, 2007.

Douglass, A. R., Schoeberl, M. R., Rood, R. B., and Pawson, S.: Evaluation of transport in the lower tropical stratosphere in a global chemistry and transport model, J. Geophys. Res., 108(D9), 4259, doi:10.1029/2002JD002696, 2003.

Eskes, H., van Velthoven, P., Valks, P., and Kelder, H.: Assimilation of GOME total ozone satellite observations in a threedimensional tracer transport model, Q. J. Roy. Meteorol. Soc., 129, 1663, 2003.

Fortuin, J. P. F. and Kelder, H.: An ozone climatology base on ozonesonde and satellite measurements, J. Geophys. Res., 103, 
31709-31734, 1998.

Geer, A. J., Lahoz, W. A., Jackson, D. R., Cariolle, D., and McCormack, J. P.: Evaluation of linear ozone photochemistry parametrizations in a stratosphere-troposphere data assimilation system, Atmos. Chem. Phys., 7, 939-959, 2007,

http://www.atmos-chem-phys.net/7/939/2007/.

IPCC (Intergovernmental Panel on Climate Change): Fourth Assessment Report (AR4), Climate Change 2007 - The Physical Science Basis, Contribution of Working Group I to the Fourth Assessment Report of the IPCC (ISBN 9780521 88009-1), http: //www.ipcc.ch/ipccreports/ar4-wg1.htm, last access: 1 September 2009, 2007.

Krol, M., Houweling, S., Bregman, B., van den Broek, M., Segers, A., van Velthoven, P., Peters, W., Dentener, F., and Bergamaschi, P.: The two-way nested global chemistry-transport zoom model TM5: algorithm and applications, Atmos. Chem. Phys., 5, 417432, 2005, http://www.atmos-chem-phys.net/5/417/2005/.

Liu, X., Chance, K., Sioris, C. E., Spurr, R. J. D., Kurosu, T. P., Martin, R. V., and Newchurch, M. J.: Ozone profile and tropospheric ozone retrieval from GOME: Algorithm description and validation, J. Geophys. Res., 110, D20307, doi:10.1029/2005JD006240, 2005.

Liu, X., Chance, K., Sioris, C. E., Kurosu, T. P., Spurr, R. J. D., Martin, R. V., Fu, T.-M., Logan, J. A., Jacob, D. J., Palmer, P. I., Newchurch, M. J., Megreskaia, I. A., and Chatfield, R. B.: First directly retrieved global distribution of tropospheric column ozone from GOME: Comparison with the GEOS-CHEM model, J. Geophys. Res., 111, D02308, doi:10.1029/2005JD006564, 2006.

Meijer, Y. J., Kelder, H. M., van der A, R. J., and van Oss, R. F.: Evaluation of Global Ozone Monitoring Experiment (GOME) ozone profiles from nine different algorithms, J. Geophys. Res., 111, D21306, doi:10.1029/2005JD006778, 2006.

National Research Council (NRC): Earth Observations from Space: The First 50 Years of Scientific Achievements, Committee on Scientific Accomplishments of Earth Observations from Space, ISBN 978-0-309-11095-2, National Academic Press, Washington DC, 2008.

RETRO final report: REanalysis of the TROpospheric chemical composition over the past 40 years - A long-term global modeling study of tropospheric chemistry, Reports on Earth System Science, edited by: Schulz, M. G., http://retro.enes.org/reports/ RETRO_Final_Report.pdf, last access: 1 September 2009, Max Planck Institute for Meteorology, Hamburg, report no. 48/2007, ISSN 1614-1199, August 2007.

Schoeberl, M. R., Ziemke, J. R., Bojkov, B., Livesey, N., Duncan, B., Strahan, S., Froidevaux, L., Kulawik, S., Bhartia, P. K., Chandra, S., Levelt, P. F., Witte, J. C., Thompson, A. M., Cuevas, E., Redondas, A., Tarasick, D. W., Davies, J., Bodeker, G., Hansen, G., Johnson, B. J., Oltmans, S. J., Vömel, H., Allaart, M., Kelder, H., Newchurch, M., Godin-Beekman, S., Ancellet, G., Claude, H., Andersen, S. B., Kyrö, E., Parrondos, M., Yela, M., Zablocki, G., Moore, D., Dier, H., von der Gathen, P., Viatte, P., Stübi, R., Calpini, B., Skrivankova, P., Dorokhov, V., de Backer, H., Schmidlin, F. J., Coetzee, G., Fujiwara, M., Thouret, V., Posny, F., Morris, G., Merrill, J., Leong, C. P., Koenig-Langlo, G., and Joseph, E.: A trajectory-based estimate of the tropospheric ozone column using the residual method, J. Geophys. Res., 112,
D24S49, doi: 10.1029/2007JD008773, 2007.

Segers, A. J., Eskes, H. J., van der A, R. J., van Oss, R. F., van Velthoven, P. F. J.: Assimilation of GOME ozone profiles and a global chemistry-transport model using a Kalman filter with anisotropic covariance, Q. J. Roy. Meteorol. Soc., 131, 477-502, 2005.

Sparling, L.C., Wei, J. C., and Avallone, L. M.: Estimating the impact of small-scale variability in satellite measurement validation, Geophys. Res., 111, D20310, doi:10.1029/2005JD006943, 2006.

Stajner, I., Wargan, K., Pawson, S., Hayashi, H., Change, L.P., Hudman, R. C., Froidevaux, L., Livesey, N., Levelt, P. F., Thompson, A. M., Tarasick, D. W., Stübi, R., Andersen, S. B., Yela, M., König-Langlo, G., Schmidlin, F.J., and Witte, J. C.: Assimilated ozone from EOS-Aura: Evaluation of the tropopause region and tropospheric columns, J. Geophys. Res., 113, D16S32, doi:10.1039/2007JD008863, 2008.

Tarasick, D.W. and Slater, R.: Ozone in the troposphere: Measurements, Climatology, Budget and Trends, Atmos.-Ocean, 46, 93 115, doi:10.3137/ao.460105, 2008.

Valks, P. J. M., de Haan, J. F., Veefkind, J. P., van Oss, R. F., and Balis, D. S.: TOGOMI: An improved total ozone retrieval algorithm for GOME XX Quadrennial Ozone Symposium, Zerefos, C. S., 1/6/2004-8/6/2004, Athens, University of Athens, 129130, 2004.

van den Broek, M. M. P., van Aalst, M. K., Bregman, A., Krol, M., Lelieveld, J., Toon, G. C., Garcelon, S., Hansford, G. M., Jones, R. L., and Gardiner, T. D.: The impact of model grid zooming on tracer transport in the 1999/2000 Arctic polar vortex, Atmos. Chem. Phys., 3, 1833-1847, 2003,

http://www.atmos-chem-phys.net/3/1833/2003/.

van den Broek, M. M. P., Williams, J. E., and Bregman, A.: Implementing growth and sedimentation of NAT particles in a global Eulerian model, Atmos. Chem. Phys., 4, 1869-1883, 2004, http://www.atmos-chem-phys.net/4/1869/2004/.

van Oss, R. F. and de Haan, J. F.: CHEOPS-GOME, Algorithm Theoretical Basis Document for OPERA, CHEOPS/KNMI/ATBD/001, Issue 1.1, 14-10-2004, 2004.

van Peet, J. C. A., van $\operatorname{der}$ A, R. J., de Laat, A. T. J., Tuinder, O. N. E., Konig-Langlo, G., and Wittig, J.: Height resolved ozone hole structure as observed by the Global Ozone Monitoring Experiment-2, Geophys. Res. Lett., 36, L11816, doi:10.1029/2009GL038603, 2009.

van Roozendael, M., Loyola, D., Spurr, R., Balis, D., Lambert, J.-C., Livschitz, Y., Valks, P., Ruppert, T., Kenter, P., Fayt, C., and Zehner, C.: Ten years of GOME/ERS-2 total ozone data: the new GOME Data Processor (GDP) Version 4: I, Algorithm Description, J. Geophys. Res., 111, D14311, doi:10.1029/2005JD006375, 2006. 